\title{
Teachers' Perceptions on Application Of 2013 Curriculum for Elementary School in Medan
}

\author{
Windha Zulhernanda*
}

Department of English Applied Linguistics (LTBI), State University in Medan (UNIMED), North Sumatera, Indonesia

Corresponding Author: Windha Zulhernanda, E-mail: windhafiz@gmail.com

\section{ARTICLE INFO}

Article history

Received: December 082017

Accepted: January 132018

Published: February 28, 2017

Volume: 9 Issue: 1

Advance access: January 2018

Conflicts of interest: None

Funding: None

\author{
Key words: \\ Perception, \\ 2013 Curriculum, \\ Teacher, \\ Elementary School
}

\begin{abstract}
Curriculum is a set of educational design programs as a guide for learning activities. Recent changes in curriculum implementation in education have an impact on teachers in implementing them. This study investigated about the teacher perception on application the newest curriculum such as the 2013 curriclum for elementary school in Medan, especially Medan Selayang subdisrict. The participant of this study were 3 teachers that taught in different public elementary school in Medan Selayang sucdistrict. There were 2 female teachers and 1 male teacher. The techniques of collecting the data by interview the teacher about application 2013 curriculum in their class. The data analysis have beenanalyzed by their perception from the their statements about the difficulties and the solution when applied the 2013 curriculum by Rao, V. S. Pand then analyzed based on the types of perception, such as Perceivers-Specific Characteristics, TargetSpecific Characteristics, Situation-Specific Characteristics.The result of this study was (1) the dominant types of the third teacher's perception was Specific Characteristics-Situation. (2) the participant gains that perception greater than the social context that surrounds it, because such social influences and citation as those listed in transcript can affect the behavior and thinking of the individual by stating that the 2013 curriculum is still a lot of flaws and should need revision again. because the participant sees the condition based on what they see, what they feel, and it will be what they think.
\end{abstract}

\section{INTRODUCTION}

Curriculum change is a long and arduous process. Administrators and teachers begin by consulting the national and state standards written for the various content disciplines that establish what should be taught at each grade level. Curriculum developers sometimes suggest how the content should be taught, but rarely do they guide educators as to how to implement the curriculum itself.

Other challenges exist in the curriculum change process. Not only do teachers lack direction regarding curriculum change, they lack the time to learn the new curriculum. Insufficient knowledge in a given discipline tempts a teacher to skim topics, regardless of the district's curriculum document. Experienced, but unmotivated, teachers can fall back on past teaching habits, teaching the new content in a lack-luster way so as to render the content of new curriculum meaningless (Orrill \& Anthony, 2003).

The word "Perseptions" always uses in our daily activity. But, what is the actual meaning of perceptions? According to Sarwono, S.W (1983:89), Perceptions is a someones' ability for organize some observation, the ability such as ability to distinguish, group and focus something that found. Because of that, someone people have the way different perceptions. It is possible because there are some distinguish in assessment system and the characteristic of their ownself.
Based on the observation, many elementary school which applied the 2013 curriculum in their school, especially in Medan Selayang District. There were 30 elementary school in there. Such as 22 private elementary schools and 8 public elementary schools. the researcher found some problems when doing the observation, such as not executed the 2013 curriculum in good way. administratively, teachers use the curriculum 2013, but in reality in the classroom, many teachers are still using the previous curriculum system that is KTSP (education unit level curriculum) 2006. The teachers still used the 2006 curriculum because the infrastructure and the fasilities not available, the teachers still confuse when applied the 2013 curriculum in elementary school because some subject joined in one theme. The researcher wasable to investigate about the teachers perception about the 2013 curriculum in elementary school and able to know the suggests for improve this curriculum.

The aim of this study were attempted to explain and describe of the teacher perceptions about 20013 curriculum in elementary school. To achieve the aim of this study following the objectives, the researcher have to formulate the research question, such as:

1. How is the teachers' perceptions of the 2013 curriculum that applied in their elementary school ?

2. What are the reasonswhen the teachers convey their perceptions about apply the 2013 curriculum in elementary school?

Published by Australian International Academic Centre PTY.LTD.

Copyright (c) the author(s). This is an open access article under CC BY license (https://creativecommons.org/licenses/by/4.0/) http://dx.doi.org/10.7575/aiac.alls.v.9n.1p.62 


\section{LITERATURE REVIEW}

\section{Perceptions}

According to Nelson and Quick (1997: 83-84) "perception is the process of interpreting information about another person." from the menaing of perception it is clear that all perceptions can depend on the information received. how you interpret the information to be true information. in other words, although the information received is the same, but still the way in which the interpretation of the person varies is based on the capacity of the way of interpreting it

Rao and Narayan (1998: 329-330) defining acceptable perceptions is dependent on a person's behavior when conveying that information that enables them to understand the situation around them, "perception is the process whereby people select, organise, and interpret sensory stimulations into meaningful information about their work environment."

This section is drawn from Nelson and Quick's (op cit: 84-87) concise description of the three major characteristics that influence our perception of other people:

- Perceivers-Specific Characteristics: The factor of this type of perception is familiarity with the object of perception. when between informants and perceivers have a good proximity, it is better to make observations to reach good decisions about a particular situation. but you should see the informant very accurately, and must produce very accurate data during the observation.

- Target-Specific Characteristics: This perception is strongly influenced by social perception. the physical appearance of an informant is very influential such as height, age estimate, and also sex. the most important is the physical appearance and feeling received by perceivers.

- Situation-Specific Characteristics: This is a very significant factor that affects the impression that is formed about someone by an individual. In other words, the Social context of the interaction is a major influence. The strength of situational cues often provides clear indications of behaviour that are acceptable within certain environmental contexts. Thus, there are particular situations that influence the behaviour of an individual, which do not necessarily affect the disposition of that individual. This is what is referred to as the discounting principle in social perception.

\section{Curriculum}

2013 curriculum is the newest curriculum concept which designed with improving the character and spiritual building, besides improving the knowledge was promoted by minister of education and culture in the beginning of 2013 and now have been revised in Permendikbud No. 24 in 2015to be implemented in Indonesian formal education.

Syllabus and KI and KD curriculum 2013 2016, for SD/ MI Class 1,2,3,4,5 and 6 containing elemental syllabus elementary syllabus, Science subject, Mathematics, Socials subject, Art and Culture Subject, Pysicals subject, Indonesian and the syllabus of the Religions subject, and Civics subject on the new revised edition have a fairly simple look, this makes it very easy for the teacher to understand and learn, only 3 syllabus columns The new k13 comprises the following framework:

1. Subject and Basic Competency (KD)

2. Learning Materials

3. Learning Activities

Syllabus, KI and KD Curriculum 2013 in 2016 seems to pay attention to the global context and the plurality of the Indonesian people, the mission and the curriculum orientation of 2013 are translated into educational practices with the specific aim that learners have the necessary competencies for the life of the community in the present and future.

Competence in question includes three competencies, namely:

(1) Master knowledge;

(2) Have the skills or ability to apply knowledge;

(3) Cultivate high spiritual and social ethical attitudes in the life of society, nation and state. Competence of spiritual attitudes and social attitudes, is achieved through indirect teaching (indirect teaching) that is exemplary, habituation, and school culture, taking into account the characteristics of subjects and the needs and conditions of learners. The growth and development of attitude competence is done throughout the learning process, and can be used as teacher consideration in developing the character of the students further.

\section{RELATED STUDY}

1. Davis, H.C. 2009. Curriculum Improvement: The Teacher Perspective on Change in the Classroom. Thesis Disertation, Professional Papers. Paper 286. This study explored the curriculum change experiences of five social studies teachers, from three high schools within one school district located in a western Montana city,integrating an economics curriculum in their eleventh grade U.S. history classrooms forthe first time. The conclusion offers several suggestions to ease the curriculum changeprocess for teachers. Teachers need the support of the community, administrators,colleagues, and outside agencies for continued, successful curriculum change. Teachers need time and space for collaboration, planning, curriculum development, and knowledge building. Teachers need to be able to easily adapt curriculum materials to their own teaching styles and district curriculum guidelines.

2. Bettin juniaria HS, et al.2017. Strategic Management in the Implementation of Curriculum 2013 in Elementary School in Indonesia. Macrothink Institute: International Journal of Learning and Development. Vol 7 No 3 . ISSN 2164-4063.This study attempts at describing and explaining: (1) the strategic plan designing activity inthe implementation of the 2013 curriculum; (2) the implementation of the strategic plans in theimplementation of the 2013 curriculum; and (3) the evaluation on the implementation of the 2013 curriculum. By finding the solutions, problems faced by the schools can be regularly solved to prevent them from affecting the teaching and learning activities. 


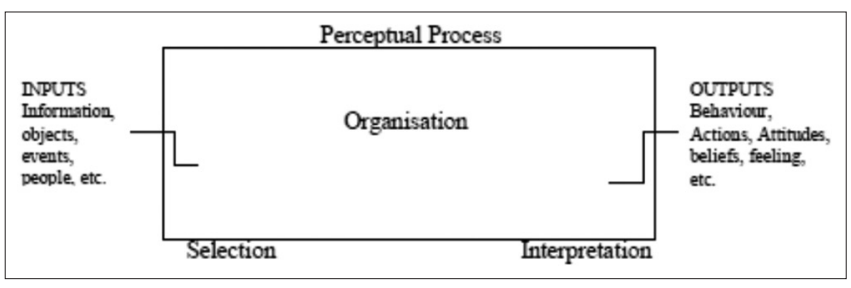

Figure 3.3.1. Model of the perceptual process

\section{RESEARCH METHODOLOGY}

\section{Subject}

In Medan Selayang District has 30 Elementary Schools. There are 22 private elementary schools and 8 public elementary schools. In this case, the researcher investigated the participants' perception which taught in public elementary schools, because in elementary schools has been required to apply the 2013 curriculum. The participant of this study were 3 teachers that teach in different elementary school in Medan Selayang sucdistrict. There are 2 female teachers and 1 male teacher. The first teacher was a teacher class in $4^{\text {th }}$ class in SDN 067245 The second teacher was a teacher class in $5^{\text {th }}$ class in SDN 066656, and the last teacher was a teacher class in $1^{\text {st }}$ in SDN 065011.

\section{Techniques of Collecting the Data}

Fontana and Frey (2003) pointed out that "asking questions and getting answers is a much harder task than it may seem at first" (p. 645). However, interviews play a centralrole in qualitative data collection procedures because they help the researcher get an indepth understanding of participants in a study.the data have been taken from interview those teacher about all of things of 2013 curriculum. The question were:

1. What is your difficulties in apply the 2013 curriculum in the class?

2. What is your solutions to solve that problem ?

3. What is the your difficulties when to make assessment system?

4. From your perspective, is it the good curriculum for elementary school that applied in the class?

5. What is your suggestion for make this curriculum be better?

\section{Techniques of Analysis the Data}

After ask the question to three teachers, we analyzed their perception from the their statements about the difficulties and the solution when applied the 2013 curriculum and then analyzed based on the types of perception, such as Perceivers-Specific Characteristics, Target-Specific Characteristics, Situation-Specific Characteristics. And then next to poerception process by Rao, V. S. P. And Narayana, P. S. (1998), input quality will determine the output. inputs such as information, object, people, event, and etc. will be processed by means of selection and interpretation and will produce output such as behavior, action, attitude, belief, and feeling.

Variables in the perceptual process:
Inputs : all events that can be from people and events received by perceiver.

Process : all results received from the perceiver, will be processed through selection and interpretation.

Outputs : results that can be after the selection process and interpretation of it

Behavior :any behavior, action, attitude, belief, and feeling from someone who will produce a new set of persception.

\section{RESULT AND DISCUSSION}

researcher found that:

Researcher : What is your difficulties in apply the 2013 curriculum in the class?

Translate to English

Teacher A : although I have 4 years applied this K13, I still still confused a little when applying it. Because at one time teaching K13 in the classroom, had to deliver some material in one theme. because K13 is now using the theme for each week. So its different with KTSP, which per subject matter is delivered in class. If K13 in one theme there is material Indonesia, Science, Social, Art and culture, Civics also. And it is interconnected according to the given theme. So to deliver the material sometimes I do not focus on any material, because it is related. Different with KTSP (unit level curriculum), we focus on teaching, and the sequence of lessons are focused, and more deeply, so engineering techniques and materials are conveyed more perfectly.

Researcher : What is your solutions to solve that problem?

Translate to English

Researcher : What is your solutions to solve that problem?

Teacher B

: yes, I have to understand again, themes per theme and material that is in that part of the theme. Because I think the material in K13 SD, the material is not in sequence like that in KTSP. itsappropriate with the theme. For example A material has been studied in theme 1 . Later meet you in Theme 6 , yes the material was again delivered. So the first time I wear this curriculum first, very not understand and the effect makes students also confused because they do not understand the material presented. Yaa, his teacher wrote confused let alone his students.

Researcher : What is the your difficulties when to make assessment system ?

Translate to English.

Teacher A : haaahh, that again makes me confused too. The material submitted is not a field 
of study, but when making an assessment, the value taken is the value of the field of study. My expectation when delivering the material per theme, assessment system is also assessed per theme. And when doing the exam is also a theme. Not a field study. So the confused students. They will be hard to understand. Because when teaching, only in writing theme 1, "title" we then convey their interrelated material. When examining the field of study,

Teacher C : But yes we learn from the experience is also. So to solve that problem like that, our teachers here also make techniques to facilitate the students to read at home. By writing also the parts of the field of study, for example in theme 1 , there is learning to read aloud, we as teachers also told the students, now, this lesson is b. Indonesia. We write also on the board. "Indonesia". So even when the students want to repeat the lesson at home is easy, it is written topic areas that exist in every theme that is taught. So when they want to read the field of science studies, just look at the title of the topic in their notebooks. So much easier.

Teacher B : Still about the scoring system that was, in every field of study there are 3 categories of assessment in accordance with aspects of KI, ie there is an assessment of knowledge, skills, and attitudes. Now this attitude is only assessed in the field of Civics and Religious studies only. It has been easier than ever before that should be in every field of study. But in every field of study must assess the knowledge and aspects of his skills as well, it is also difficult. Due to confusion make a judgment for the field of skills in the field of study of Mathematics and Socials for example. It is desirable that the assessment be specialized in areas that are specific to its skill assessment, eg study subjects of religions, pysiscals, art and culture, Indonesian, English, and etc.

Researcher : From your perspective, is it the good curriculum for elementary school that applied in the class?

Translate to English.

Teacher C : if I think personally, K13 is suitable but there must be revision and revision again. Why ? because K13 is more to teach how to be good. In K13 I think it's a curriculum that builds student character. Students are expected to have a better, more courteous attitude. And also students are expected to be more active in absorbing the knowledge conveyed by teachers using the props earlier. Social relations between students, as well as between students and teachers was more in optimize.

Teacher A : But... what needs to be revised before is his scoring system. Too much. And also others like I said before. But in my opinion, this K13 can only be applied to schools that can afford it. Able in terms of advice and infrastructure as well as from the competence of his students as well. Because not all schools are adequate from the aspects of his suggestions and infrastructure, so how he applied learning using props. Expected props that exist in the environment around, yaa as I said earlier, not all teachers are able to make the props (media).

Teacher B : Then the scoring system using the computer, that's a difficult thing for some teachers. If the young teacher teacher, maybe the same he easily use the computer, because it's everyday tools that he holds. Because generally it is in public schools, few young teachers and teachers are able to operate computers except in private, all teachers are proficient in technology. Well, even if the private schools are advanced.

Researcher : What is your suggestion for make this curriculum be better?

Teacher $\mathrm{C} \quad$ : It needs to be revised again in terms of assessment as I said earlier, then need to consider again, how this curriculum can be applied to inadequate schools in terms of advice and infrastructure. Like the schools that exist in the suburbs and in the villages. So that all schools can apply this curriculum. That is all.

The interview result, $\mathrm{i}$ got some cases about the teacher difficulties in apply the 2013 curriculum.

The difficulties that experiened by the teachers:

1. Teachers are still confused with the learning system of the theme.

Because in one theme included 6 subject in there, such as Indonesia, science, social subject, civics subject, and art subject.

The should explained all of 6 subject that related with the theme in one meeting. One meeting in the 2013 curriculum have one week.

2. Supporting infrastructures and other facilities for learning process are less available. And the teacher was not able to make their own media

In the 2013 curriculum, the teachers should have the variation media for adding or supporting the material for easy to understand the material by the students.

But, in their school have a little media, and the the teacher can not make some the media that related with theme. 
3. A confusing assesment system because there are three parts of assessment aspects in each field of study or each subject, ie affective, cognitive, and psychomotor. But the application in the class uses a theme not subject per subject.

It is one case that make the teacher complicated. And others, the teachers should make the descriptions about the every single students development in the class

So, the output that contain about the behaviour, attitudes, actions, belief, and feeling the teachers. From behaviour, Teachers do not completely disagree with the use of this 2013 curriculum. There is some parts that the teachers is very support to apply this 2013 curriculum. that is the based objectives or the concept of this 2013 curriculum. that is for character building and improve the students behaviour and spiritual be better, so not only develop their knowledge.

So their attitudes when apply the 2013 curriculum is they do not apply this new curriculum so well. In the administratively teachers use this 2013 curriculum program, but it's different when they apply the 2013 curriculum. The attitudes and action of teachers in the class become not perfect when applying this 2013 curriculum. Their belief and their feeling the teachers' perceptions of about the 2013 curriculum is the ardous curriculum with the complicated system.

\section{CONCLUSION}

Although the curriculum has changed, but the teachers are still applying the before curriculum.

Therefore, will make them easy to teach in their classs, not make them confuse with all of complicated system according to them.

Based on the data analysis, it has found difficulties derived from teachers and resources from the school itself. From the teachers, teachers are less understanding in the making of media and less able to make it for the learning process. similar with Huda (2010) state that the school must apply some school rules and must meet all the required facilities at the school o be well-maintained and well-guaranteed to achieve the goals of the school. Because of the school, less available media-related learning materials. and also teachers are still confused in applying this 2013 curriculum class, because it has joined the material is delivered. and also from the assessment system there are some confusing things.

Implications for education:

1. There is need more meetings to convey the directions about the 2013 curriculum.
2. Need to be provided facilities and infrastructure that support for learning activities

3. Need to be trained into the reality in the classroom, if possible minute per minutes and focus for one theme. In order for teachers to better understand how to apply the newest curriculum in the classroom

\section{REFERENCES}

Bettin juniaria HS, et al.(2017). Strategic Management in the Implementation of Curriculum 2013 in Elementary School in Indonesia. Macrothink Institute: International Journal of Learning and Development. Vol 7 No 3. ISSN 2164-4063.

Cronbach, L.J. (1990). Essentials of Psychological Testing ( $5^{\text {th }}$ ed.). New York: Harper and Row Publishers

Davis, H.C. (2009). Curriculum Improvement: The Teacher Perspective on Change in the Classroom. Thesis Disertation, Professional Papers. Paper 286.

Fontana, A., \& Frey, J. (2003). The interview: From structured questions to negotiated text. Thousand Oaks: Sage

Grondlund, N. E. (1982). Constructing Achievement Test ( $3^{\text {rd }}$ ed.). En-glewood Cliffs, NJ: Prentice-Hall, Inc.

Huda, M. (2010). Kajian Filosofis Otonomi Daerah Bidang Pendidikan. Malang: FIP-UM

Orrill, C., \& Anthony, H. (2003). Implementing reform curriculum: A case of who's in charge.Annual Meeting of the American Educational Research Association. Chicago.

Peraturan Pemerintah Republik Indonesia Nomor 13 Tahun 2015 tentang Perubahan Kedua atas Peraturan Pemerintah Nomor 19 Tahun 2005 tentang Standar Nasional Pendidikan.

Peraturan Pemerintah Nomor 24 Tahun 2015 tentang Standar Nasional Pendidikan

Peraturan Menteri Pendidikan dan Kebudayaan republik Indonesia Nomor 24 tahun 2016 tentang Kompetensi Inti dan Kompetensi Dasar Pelajaran Pada Kurikulum 2013 Pada pendidikan dasar dan pendidikan menengah

Quick, D.L. and Nelson, J.C. (1997), Organisational Behavior: Foundations, Realities, and Challenges, (New York: West Publishing Company), pp. 83-84.

Rao, V. S. P. And Narayana, P. S. (1998), Organisation Theory and Behaviour, (Delhi: Konark Publishing Company), (329-330)

Sarwono, S.W. (1983). Pengantar Umum Psikologi. Jakarta: Bulan Bintang. 